Вісник Львівського університету. Серія філос.-політолог. студіi. 2020. Випуск 31, с. $63-69$

Visnuk of the Lviv University. Series Philos.-Political Studies. Issue 31, p. 63-69

UDK 141.7(477)

DOI https://doi.org/10.30970/PPS.2020.31.8

\title{
UKRAINIAN HUMANISTS ON THE ROLE OF MAN IN SOCIETY (1st HALF OF THE 16th CENTURY)
}

\author{
Ruslana Mnozhynska \\ Kyiv National University of Technology and Design, \\ Department of Philosophy, Political Science and Ukrainian Studies \\ Nemyrovycha-Danchenko str., 2, 01011, Kyiv, Ukraine
}

In contrast to the medieval man, whose views were turned to the cosmic Creator, whose search was carried out in the depths of his own self-consciousness, in consciousness, XVII century man's search for ways to become like God is felt not only through self-immersion and inner mystical enlightenment, but also through self-affirmation in earthly life, through creativity, through a directed purpose. Thinking of herself as the unity of soul and body, he longed for the harmonious satisfaction of his spiritual and bodily needs. Considering man as a being, by nature inclined to goodness and love, Ukrainian humanists advocated high moral relations between people in society, including and among people.

Humanists rehabilitated the material-sensory world and the sensual nature of man. The problem of the relationship between justice and law has always been the same, starting from antiquity, but it has not always been solved in the same way. We can safely say that in Ukraine, starting from the princely period until the second half of the 16th century, that, regardless of the dominance of religious values, it is corresponding to the earth. Domestic thinkers considered man to be the creator of their happiness, able to understand and return to themselves for the benefit of all the wealth and diversity of the surrounding nature, capable of creating. A characteristic feature of national humanism was the desire to create a new ideal of human virtue, the call for self-realization of man in earthly life, in society. The constant motive of humanistic philosophy was the glorification of personal virtues and merits as a measure of human dignity. The idea of Ukrainian humanists about a virtuous life included the need for active earthly self-affirmation in various spheres of human activity. Our humanists were impressed by the central principle of the ethics of humanism - the principle of the common good (the good of the people), according to which patriotism, service to the state, social activity were based on the subordination of private interests to the common good. Domestic humanists were perhaps the first in Europe to proclaim that the welfare of the people was the highest law and goal of state power; developed the idea of natural law, which was considered to be superior to human laws, which can be changed if necessary. In the period under consideration, a set of ideas that are now called the ideas of civic humanism also come to the fore: national self-consciousness, patriotism, civic service, justice, and political freedoms. The popularization of these ideas by Ukrainian humanists made a significant contribution to the future victorious national liberation war of the Ukrainian people under the leadership of B. Khmelnytsky.

Key words: freedom of will, soul, good, evil, humanism, society, God.

In Ukraine, Renaissance-humanistic views on the role of man in society were formed under the influence of the doctrine of "human autocracy" and the corresponding knowledge known from the princely era. The problem of freedom of will was considered not only in relation to the created natural order, the coincidences of fortune, but also in relation to God, his plan, which is important to people. In accordance with the tradition of Ukrainian philosophical thought established since the princely days, man, in spite of his divine determination in advance of his destiny, within the limits set by the future. According to the established even with princely

(C) R. Mnozhynska, 2020 
traditions of the Ukrainian philosophical thought her salvation depended on her willingness and ability to make the right choice between good and evil, listen to the arguments of reason, to take the path of virtue and moral self-improvement, to exercise moderation and restraint against the temptations and unhealthy passions. In the Renaissance era, a different understanding of man emerges and the interpretation of free will changes accordingly.

Man is presented as a "happy mortal God". It is capable of because of his intelligence and active activities to reveal the earth's secrets, get to know the beauty of heaven and the laws of motion of heavenly bodies, to create literature, art, the laws of social life itself, in the end, able to become the Creator of your own destiny, even try to attract the changing fortune and the like. Will, therefore, have gained the greatest possible freedom, a means of limitation were primarily the human mind. The concept of free choice called "tyranny" of the soul, led to the conclusion that everyone having a free choice between good and evil controls their own destiny because her destiny in her own hands. Approval L. Zizaniya about the despotism of man and its ability of mind to control his will continued the rationalist tradition of the domestic doctrine of the autocracy of the XV - beginning of XVI century, giving it a certain humanistic sound.

Useful to society a person can be only when your soul knows and will find their place in society, according to the desire of the soul.

K. Sakovych made the greatest contribution to the development of the problem of the relationship between soul and body. Referring to the committed V. Nychyk detailed analysis of his philosophical views, let's briefly clarify the main points of his understanding of this problem. Sakovych was the first in Ukraine to study and extensively comment on Aristotle's "Treatise on the Soul" and used it for his theoretical constructions [5, p. 178]. In the "Treatise on the Soul" he dwells on such important issues at that time as the question of the essence of the soul, its role, abilities, location, location after death. In addition, a separate section is devoted to the last question "On the state of the soul after its separation from the body and whether the soul dies together with the body"). The knowledge of the soul, which is the noblest creation, wrote the thinker, not only beautiful and high, but also very necessary for our salvation. It is precisely because of the ignorance of the nature of the soul, its properties and abilities that many false thoughts have spread among people. "It was once written in law: it is indecent for a citizen not to know the laws of his homeland", - Sakovych continues. - "And I can say: it is even more indecent for a person not to know the laws of his nature, not to know the properties and duties of the members, of which his body consists, not to know what he has gathered" [4, p. 156]. However, at the end of the XVI century in Ukraine, there have been significant changes in the understanding of the meaning of life and the place of man in society. The spread of Renaissance-humanist ideas created a new image of man and the world, led to the understanding of man as a creative personality, able to create themselves and change the world. The meaning of human life was seen not only in the service of God, but also in the realization by man of his earthly destiny, in the active activity, where the creative potential of man, his knowledge can be realized, level and satisfy the desire for earthly glory and immortality in her name. This is observed in such Ukrainian figures as, for example, K. Tranquillion-Stavrovetsky, S. Pekalid, M. Smotrytsky, an anonymous author of a speech in honor of T. Zamoyskiy. And although for some of them the destiny of man, the ultimate goal of his life, remained the attainment of the otherworldly salvation, but it was also believed that it could be achieved thanks to the attainment of good. For S. Oryhovsky, in particular, the meaning of life was to achieve happiness and personal freedom, which he considered an invaluable treasure. The thinker had an optimistic view of human life, in which, in his opinion, harmony and happiness can be achieved [4, p. 98]. In his search for the ultimate goal of human life, he dwells on Aristotle's assertion that "virtue and science are two things that our mind loves from birth and birth". 
Among Ukrainian humanists, the idea of the importance of earthly self-affirmation of man was formed, a new type of personality appeared, which began to realize its self-worth. Therefore, the artists of that time testified to their authorship in writing books and prefaces to them (earlier, the authors remained, as a rule, anonymous, believing that their services were the same). This applies primarily to K. Tranquillion-Stavrovetsky, E. Pletenetsky, Z. Kopystensky. Humanists contrasted the traditional belief in the sinfulness and depravity of human nature with the belief that man is the highest value and it stemmed from the nobility of his spirit. The nobility of blood, which was crucial in the Middle Ages, they pushed into the background. As for S. Oryhovsky, he saw the greatest value of earthly life in the acquisition by man of such traits of spiritual perfection, thanks to which it will remain in the future. This was fully embedded in the Renaissance perception of earthly life as a unique value, the highest good for man.

Different from the rigid hierarchical structures of feudal society in which the individual did not occupy an independent place, a his rights and obligations were determined mainly his caste affiliation and tradition, it was consecrated, the humanists of the Renaissance (Pico dela Mirandola, N. Ficino, N. Kuzanskyy, L. Vala) proclaim the liberation of man from all obligations anonymous "whole" and put forward the ideal of a holistic, comprehensively developed personality. On the territory of Ukraine from the Kyivan Rus, despite the tendency to typify of the image of man, some muted interest in individual personality in man (one of the characteristics of contemporary culture), the ideal of individualism, which confronted medieval corporatism, vividly expressed in the carefully defined sense of uniqueness and rarity of his time [3, p. 48]. The testimony of one of the highest signer of human beings in terms of Kyivan Rus can be the "instructions" of Prince Volodymyr Monomakh. These traditions appeal to individual personal in man developed in Rangoon era in Ukraine. As in Western Europe, in Ukraine there was a growing interest in human personality, outer galaxy the perception of the person as a unique individual, the Creator himself.

The chanting of heroic personality, her valor, virtue, and talent are found in many epigrams that, as well as prefaces to printed books signed by their authors, not anonymous, certifying the Renaissance-humanistic orientation of the attitude of Ukrainian intellectuals and artists. To justify the divine essence of man, the importance of contemplative activities turned to Neoplatonism. Of course, in Eastern Europe there was a surge of Renaissance individualism, which was characteristic of the Italian Renaissance. But the Ukrainian humanists also developed the ideas of humanistic anthropocentrism characteristic features of the spontaneous self of the individual in its purely earthly dimension. Focus on individual outstanding qualities of a person is observed, in particular, in the scribes. A significant place in their work is given to the glorification of individuals, primarily the magnates, social and religious figures and their actions. Praised outstanding personality C. Klenovych, S. Orykhovskyy, L. Zizany, K. Trankvilion-Stavrovetsky, Z Kopystensky. In particular, C. Klenovych like other humanists of the Renaissance were praised precisely those features of human nature, which the medieval Church considered sinful manifestation of excessive pride because they contradicted propound her obedience, meekness and uniformity in the behavior and mindset of the flock.

In contrast renaissance writers who imagined a faceless mass of people associated with a particular state or Corporation, I spoke to them on "you", without mentioning himself, Klenovych speaks about himself in the first person, "I" to his companion, according to the custom of the humanists, drawn to you. Like you can see in works by S. Oryhovsky, who also has autobiography, full of undisguised pride for his "I" and awareness of self-worth. The author writes in the third person, as "Stanislaw Oryhovsky", which puts it near the most important events of the state [1, p. 200]. As for Erasmus, for the Oryhovsky each person had a self-sufficient 
value. Against the humiliation of the human personality was made by L. Zizany, which relied on the already mentioned doctrine of "autocracy". Contrary to medieval conceptions of man as sinful and totally dependent upon the grace of God, in the speeches of Ukrainian anonymous author of the end of XVI - early XVII century, was approved Renaissance-humanistic ideal of man, endowed with an invincible power of body and spirit and is able even to subdue fate of their plans [6, p. 218]. In the Renaissance people were viewed as being active, creative. They were considered the Creator of their earthly existence, can turn to their advantage the richness and diversity of the natural environment. Activity was protestant fate, and this contrasted sharply with the medieval ideal of passive introspection, the aim of which was the expectation of the descent of the supernatural light of grace. In the first place now are not the exploits of the monk-ascetic, separated from the world in your prayer, an active social and creative activity of the outstanding personality.

Such a view of man in Ukraine had a long tradition. In the princely era, the doctrine of the autocracy of man assumed his understanding of as active subject of the action [2, p. 118]. During the period under review Ukrainian thinkers continued to develop these achievements of the previous epoch. To create a new ideal of the Renaissance man and its role in society, they relied on the teachings of K. Salutat, E. Rotterdam, also used the achievements of ancient and medieval Neoplatonism.

One of the ideological take of the Renaissance was the denial of the medieval ascetic morality, and the assertion of an optimistic view of life, rehabilitation, life-enjoyment of man. The medieval asceticism of the humanists of the Renaissance opposed the pursuit of well-being, a reasonable approach to the bounty of life. Admiration for the beauty of nature, the vitality were the dominant motifs in the works of many Western European humanists, such as K. Salutat, J. Bruno, L. Vala [4, p. 108]. Ukrainian thinkers, although he was prone to self-knowledge, does not deny the right of man to aesthetic admiration of the beauty of the earth and all that is therein, and the right to bodily joys. These views in one form or another expressed S. Oryhovsky, K. Trankvilion-Stavrovetskyy, L. Zizany, S. Pekalid, etc. For Renaissance thinkers the main qualities were the virtues of dignity, courage, kindness, prudence, generosity. Peculiar they believed can only be people of great learning and culture. A characteristic feature of domestic humanism was the desire to create a new ideal of human virtue, a call to self-actualization in this life, in society, flourishing of the Humanities. The permanent motive of the humanistic philosophy was the exaltation of personal virtues and merits as a measure of human usefulness. Representation of Ukrainian humanists of a virtuous life included the need for active earth assert themselves in various spheres of human activity.

The concept of virtue embraced traits such as integrity, courage, energy, prudence, foresight, the desire to gain personal glory. S. Orykhovsky is understood as the virtue of chastity: "I prefer to leave the beloved homeland than chaste life" [4, p. 68]. To revive this virtue in the Catholic Church and he advises the Pope. For the approval of their innocence and virtue, says the thinker, the person must use the natural intelligence and ingenuity. S. Pekalid says the Renaissance-humanistic in its basis the idea of a person's ability on their own, thanks to the virtue or valor, to rise to the level of godliness, to achieve earthly immortality. He dreams of a time when going to disappear "criminal madness" and the reign of virtue.

Especially big attention was paid to the humanists of the Renaissance the problem of human dignity, which they argue in their philosophical treatises, and artistic creativity. In their view, every person endowed with freedom of choice, unlimited ability to create its own inner world and to influence the external circumstances of her life, and the ability to set ourselves high goals and achieve them - that they had seen her dignity. Gregory Sanotsky Renais- 
sance humanistic idea of human dignity is manifested as a belief in the ability to improve itself [2, p. 108]. Self-esteem, sense of dignity of the people of the third estate, which mainly belonged to members of the academic circle of the Lavra printing house in Kyiv was not invested within the medieval understanding of human dignity that was defined by belonging to a certain stage in the feudal social hierarchy. Subject to the approval of the high dignity of man is ever-present in contemporary literature, art, philosophy. The importance of the Ukrainian humanists attached, and other manifestations of virtue, as courage, honesty, truthfulness, kindness, prudence, wisdom, judgment.

In the middle ages people valued famous primarily for the aristocratic origin, antiquity of race, titles. It formed the social inequality of people. Generosity is respected as an essential feature of high birth: aristocrat only admitted capable of genuine greatness of soul, heroic deeds. But humanists put a person's importance is dependent on his personal qualities, personal virtue, talent, and skills to implement them. The representative of the aristocratic family, according to the humanists, must earn the respect of her noble deeds, public and creative activity of the outstanding personality.

Such a view of man in Ukraine had a long tradition. In the princely era, the doctrine of the autocracy of man assumed his understanding of as active subject of the action [2, p. 118].

A view of man in Ukraine had a long tradition. In the princely era, the doctrine of the autocracy of man assumed his understanding of as active subject of the action [2,p. 118]. During the period under review Ukrainian thinkers continued to develop these achievements of the previous epoch. To create a new ideal of the Renaissance man and its role in society, they relied on the teachings of K. Sanotsky drew attention to the fact that, since people are concerned primarily with their material interests, it is possible to force their minds only by careful care for their satisfaction. Rehabilitation of the human body and sensory sphere is taking place. Ukrainian humanists were not against the passions and the expression of emotions, which, incidentally, saturated their works (especially poems, epistles, speeches, panegyrics), but they respected. Ukrainian humanists also considered the right to aesthetic pleasure, the realization of personal interest, and the desire for socially useful work to be natural to man. They, in particular, glorify Prince K. Ostrozky for taking care of the ancient Roman muses in the Ostroh school (S. Pekalid). In S. Pochasky we see the fascination with "singing of merry chants"; "Exercises in singing with instrumental accompaniment", etc. Thus, humanistic thought in Ukraine insisted on the right of man to aesthetic pleasure and harmonious development.

The glorification of man, his talent, ability to create, admiration for the beauty of nature is inherent in the poetry of Pavlo Krosnensky and Jan Vyslotsky. In the spirit of Renaissance humanism, Pavlo Krosnensky considered poets to be "inspired by the heavenly deity". Domestic thinkers considered man to be the creator of their happiness, able to understand and return for their benefit all the wealth and diversity of the surrounding nature, able to create. Yuri Drohobych was aware of the social significance and usefulness of his work.

Ukrainian humanists believed that nature not only gave man the sense organs that allow him to enjoy the beauty of the world, but also created this very thing. The desire for beauty, in their opinion, is inherent in man by nature. That is why a person has the right to enjoy the beauty of the earth and everything on it. Explanatory descriptions of nature, where it acts as an object of aesthetic pleasure, are present in the poems of S. Klenovych, I. Dombrovsky, S. Pekalid, S. Shimonovych and others. The latter, in particular, in his work "Reapers" in a typical Renaissance spirit depicts the beauty of a summer day, the central figure of which is the "beautiful sun, the second day of the day". 
Conducted on the basis of analysis of creation of the Ukrainian humanists reconstruction of their looks to the problem of correlation of God and world, role of man, in society, allows to draw conclusion, at first, about the presence of two tendencies in their going near its decision, namely is an attempt of rapprochement of God with nature, subsoil for which was Neoplatonism, which acquired renaissance interpretation, and attempt to limit absolute lordship of God over the world by the created laws them. Secondly, about beginning of gradual reorientation of the Ukrainian philosophical idea from cognition of God to cognition of nature.

\section{References}

1. Gorsky V.S. History of Ukrainian philosophy. Teaching. Kyiv : Naukova dumka, 2019. 375 p.

2. Kolodny A.M., Filipovich L.O. Religious spirituality of Ukrainians: manifestations, figures, status. Lviv : Logos, 2016. 184 p.

3. Kraliuk P. Peculiarities of the Manifestation of National Consciousness in Ukrainian Public Thought XVI - trans. gender XVII century. Lutsk : Nadstyrya. 2016. 132 p.

4. Lytvynov Volodymyr. Renaissance humanism in Ukraine (Ideas of humanism of the Renaissance in Ukrainian philosophy of the XV - early XVII centuries). Kyiv : Osnovy, 2000. 472 p.

5. Nichik V.M. Reformation and humanistic ideas in fraternal schools / Nichik V.M., Litvinov V.D., Stratiy Y.M. Humanistic and Reformation Ideas in Ukraine (XVI early XVII centuries) Kyiv. 1990. 300 p.

6. Rogovych M.D. Ukraine and the Northern Renaissance. Philosophy of the Renaissance in Ukraine. 1990. 300 p.

\section{УКРАЇНСЬКІ ГУМАНІСТИ ПРО РОЛЬ ЛЮДИНИ В СУСПІЛЬСТВІ (ПЕРША ПОЛ. ХVІ ст.)}

\section{Руслана Множинська}

Київський національний університет технологій та дизайну, кафедра філософії, політології та українознавства вул. Немировича-Данченка 2, 01011, м. Київ, Україна

На відміну від середньовічної людини, погляди якої були звернені до космічного Творця, пошуки якого здійснювались у глибинах власної самосвідомості, в українському суспільстві кінця XVI - поч. XVII ст. відчувається пошук людини шляхів уподібнення до Бога не тільки через самозаглиблення і внутрішнє містичне осяяння, а й через самоутвердження в земному житті, через творчість, через спрямовану назовні суспільну активність. Мислячи себе як єдність душі і тіла, вона прагнула до гармонійного задоволення своїх духовних і тілесних потреб. Розглядаючи людину як істоту, від природи схильну до добра й любові, українські гуманісти виступали за високоморальні стосунки між людьми в суспільстві, в тому числі й між чоловіком і жінкою.

В епоху Відродження на зміну середньовічному аскетизму, самозаглибленості, зосередженню на пізнанні Бога i підпорядкуванню життя меті потойбічного спасіння прийшло стихійне самоутвердження людини в різних сферах діяльності, сформувався ідеал всебічно розвиненої особистості, було проголошено право людини на задоволення всіх її земних потреб.

Гуманісти реабілітували матеріально-чуттєвий світ і чуттєву природу людини. Проблема відношення справедливості й права стояла завжди, починаючи від античності, але не завжди однаково розв'язувалась. Можемо сміливо стверджувати, що в Україні починаючи від княжої доби аж до другої половини XVI ст., не зважаючи на домінування релігійних цінностей, відповідне місце відводилось також і земним потребам та суспільним інтересам людини. Характерною рисою вітчизняного гуманізму було прагнення до створення нового ідеалу людської доброчесності, заклик 
до самореалізації людини у земному житті, в суспільстві, розквіту гуманітарного знання. Сталим мотивом гуманістичної філософії стало звеличення особистих чеснот і заслуг як мірила людської повновартості. Уявлення українських гуманістів про доброчесне життя включало в себе необхідність активного земного самоутвердження у різних сферах людської діяльності. Нашим гуманістам імпонував центральний принцип етики гуманізму - принцип спільного блага (блага народу), за яким патріотизм, служіння державі, суспільна активність грунтувалися на підпорядкуванні приватних інтересів спільному благу тощо. Вітчизняні гуманісти чи не першими в Європі проголошували, що благо народу є найвищим законом і метою державної влади; розробляли ідею природного права, яке вважали вищим за людські закони, що їх за потреби можна й змінювати. У розглядуваний період на перший план виступає також комплекс ідей, які називають нині ідеями громадянського гуманізму: національна самосвідомість, патріотизм, громадянське служіння, справедливість, політичні свободи. Популяризація цих ідей українськими гуманістами зробила свій вагомий внесок у майбутню переможну національно-визвольну війну українського народу під проводом Б. Хмельницького.

Ключові слова: свобода волі, добро, зло, душа, гуманізм, суспільство, Бог 